\title{
PENALARAN MORAL SISWA BERINTELIGENSI TINGGI DITINJAU DARI GAYA PENGASUHAN ORANG TUA
}

\author{
Nurhayani \\ IAIN Sumatera Utara \\ nur_hayanii@gmail.com
}

\begin{abstract}
This research"s goal was to know the differences of moral reasoning between students with high intelligence that have authoritarian, authoritative, and permisive parenting style. The data collected from 815 th grade students in Muhammadiyah elementary school in Sapen, Yogyakarta. This research data was using two scales, moral reasoning scale and perception of parenting style scale. Two ways ANOVA was used to analyze the data. The result showed that parenting style and gender interacted and effected the moral reasoning of the student $(F: 5,580 ; p=0.006<0.05)$, so it can be concluded that there was a differences between male and female student that have authoritarian, authoritative, and permisive parenting style. It is important for educators to develop a teaching strategies that can develop students positive aspect.
\end{abstract}

Keywords: Moral Reasoning, Student With High Intelligence, Parenting Style

\begin{abstract}
Abstrak
Penelitian ini bertujuan untuk mengetahui perbedaan penalaran moral antara siswa berinteligensi tinggi yang memperoleh pola asuh otoriter, otoritatif dan permisif. Subjek penelitian ini adalah 81 orang siswa berinteligensi tinggi kelas $V$ di SD Muhammadiyah Sapen Yogyakarta. Data penelitian ini dikumpulkan dengan menggunakan dua skala, yaitu skala penalaran moral dan skala persepsi pola asuh orang tua. Analisis Varians dua arah (Two Ways ANOVA) digunakan sebagai metode untuk mengalisis data. Hasil analisis data menunjukkan bahwa pola asuh dan jenis kelamin saling berinteraksi dalam mempengaruhi penalaran moral siswa berinteligensi tinggi ( $F: 5,580 ; p=0.006<0.05$ ) sehingga disimpulkan ada perbedaan penalaran moral antara siswa laki-laki dan perempuan berinteligensi tinggi yang memperoleh pola asuh otoriter, otoritatif dan permisif Berdasarkan temuan di atas, disarankan bagi pendidik, hendaknya mengembangkan strategi mengajar yang tepat yang dapat mengembangkan aspek positif bagi anak berinteligensi tinggi dengan

(a) menghindari stereotip peran jenis kelamin; (b) memberi dorongan bagi anak beringeligensi tinggi untuk independent dan berani mengambil resiko; (c) membimbing mereka dalam perilaku problem solving dan strategi pengambilan keputusan moral. Sedangkan bagi orang tua, hendaknya menghindarkan pola pengasuhan atau tuntutan (harapan) yang berbeda bagi anak laki-laki dan perempuan dan membantu mereka menetapkan batasan-batasan dalam membuat keputusan moral secara tepat sehingga terhindar dari masalah penyesuaian sosial.
\end{abstract}

Kata Kunci: Penalaran Moral, Anak Berinteligensi Tinggi, Pola Asuh 


\section{PENDAHULUAN}

Anak adalah penentu masa depan bangsa dan setiap anak di dunia ini memiliki potensi diri yang dapat dan perlu dikembangkan melalui pendidikan yang baik, yakni sebuah pendidikan yang dapat memfasilitasi mereka menjadi insan-insan yang bermoral sehingga dapat menjadi warga Negara yang berpribadi mulia. Hal ini jelas dinyatakan dalam UU RI nomor $23 \mathrm{~b}$ dan $23 \mathrm{c}$ tahun 2002, bahwa anak adalah tunas, potensi, dan generasi muda penerus cita-cita perjuangan bangsa, memiliki peran strategis dan mempunyai ciri dan sifat khusus yang menjamin kelangsungan eksistensi bangsa dan negara pada masa depan; dan agar setiap anak kelak mampu memikul tanggung jawab tersebut, maka setiap anak harus mendapat kesempatan yang seluas-luasnya untuk tumbuh dan berkembang secara optimal (Kartika, 2005).

Anak berinteligensi tinggi adalah aset negara, yang perlu mendapat perhatian khusus sehingga mereka diharapkan mampu menghasilkan karyakarya yang gemilang. Anak berinteligensi tinggi membutuhkan pengalaman belajar yang sama dengan anak-anak pada umumnya dalam mendapatkan kesempatan untuk memperoleh pengalaman belajar yang dapat mendorong mereka untuk lebih peduli terhadap orang lain dan dengan kelebihankelebihannya dapa membantu anak lain berkembang secara optimal. Namun tingginya aspek intelektual pada anak berinteligensi tinggi berpengaruh sangat besar terhadap perkembangan personalitasnya yang dapat berdampak terhadap perkembangan sosialnya. Kapasitas intelektual yang tinggi membuat anak berinteligensi tinggi mempersepsi rangsangan sosial jauh lebih tinggi dari tahap penalaran moral anak-anak seusianya sehingga mempersulit anak berinteligensi tinggi dalam melakukan penyesuaian sosial dan menimbulkan konflik baik dalam dirinya sendiri maupun orang lain di sekitarnya.

Undang-undang RI No. 2 Tahun 1998 tentang sistem pendidikan nasional, bab III pasal 8 ayat 2 menyatakan bahwa warga negara yang memiliki kemampuan dan kecerdasan luar biasa berhak memperoleh perhatian khusus. Hal ini ditindaklanjuti dalam GBHN tahun 1998 yakni sasaran bidang pembangunan lima tahun ke-7 adalah memberi perhatian dan pelayanan khusus bagi peserta didik yang mempunyai kemampuan dan kecerdasan luar biasa agar dapat dipacu perkembangan prestasi dan bakatnya tanpa mengubah potensi lainnya (Widyastono, 2005).

Program akselerasi atau program percepatan merupakan suatu program untuk mempercepat masa studi bagi peserta didik yang memiliki tingkat kecerdasan luar biasa sehingga dapat dipacu perkembangan prestasi dan bakatnya. Program percepatan bagi siswa berinteligensi tinggi ini memang dirancang menjadi kelas unggulan, namun demikian, program akselerasi memungkinkan siswa kurang memiliki kesempatan luas untuk belajar mengembangkan aspek afektif. Padatnya materi yang harus mereka 
terima, banyaknya pekerjaan rumah yang harus mereka selesaikan, ditunjang kemampuan intelektual yang dimiliki dan teman-teman sekelas yang rata-rata pandai, membuat iklim kerja sama mereka menjadi terbatas karena masing-masing siswa mampu menyelesaikan sendiri. Penyelenggaraan kelas akselerasi sering memunculkan anggapan kelas akselerasi adalah kelas yang terbaik jika dibandingkan dengan kelas reguler, dan didukung dengan prestasi luar biasa yang dapat mudah diraih tentunya memungkinkan pada diri siswa-siswa kelas akselerasi memiliki sikap merasa lebih unggul atau superior, suka memaksakan kehendak serta memandang rendah orang lain.

Aspek psikologis secara khusus dapat mempengaruhi penalaran moral. Hal ini dikarenakan karena ketika berhadapan dengan masalah yang kompleks individu akan menanggapinya dengan mengurangi masalah pada tingkatan mana masalah itu dapat difahaminya. Setiap anak memiliki kemampuan yang berbeda dalam menyikapi suatu masalah. Anak berinteligensi tinggi khususnya, dimana kapasitas intelektualnya yang sangat tinggi menyebabkan munculnya ketidakmampuan anak memahami dirinya yang dapat berakhir dengan munculnya perasaan ditolak atau kurang dimengerti oleh lingkungannya sehingga anak berinteligensi tinggi sering mempersepsi sinyal-sinyal sosial secara tidak tepat akibatnya berpengaruh terhadap berfungsinya pemikiran moral untuk berperilaku sesuai situasi sosial.

Setiap orang tua pada dasarnya menginginkan anak-anaknya tumbuh menjadi individu-individu yang matang dan dewasa secara sosial, tetapi para orang tua anak berinteligensi tinggi sering tidak menyadari bahwa pola pengasuhan tertentu dapat membawa dampak yang merugikan anak, khususnya dalam perkembangan sikap-sikap atau nilai-nilai positif perilaku anak dan menentukan bagaimana konsep dan penalaran moral anak. Pola pengasuhan orang tua sangat menentukan bagaimana konsep dan penalaran moral anak berinteligensi tinggi sehingga anak berinteligensi tinggi tidak mengalami hambatan dalam penyesuaian sosialnya. Inilah yang mendasari peneliti untuk melakukan penelitian lebih lanjut dalam usaha mencari penjelasan tentang bagaimana penalaran moral siswa berinteligensi tinggi ditinjau dari pola asuh orang tua.

Penelitian ini bertujuan untuk mengetahui perbedaan penalaran moral antara anak berinteligensi tinggi laki-laki dan perempuan yang memperoleh pola asuh otoriter, otoritatif dan permissif sehingga dapat dimanfaatkan untuk mengkonseptualisasi kebutuhan-kebutuhan apa saja yang diperlukan untuk mengatasi masalah yang muncul dikarenakan karakteristik anak secara internal dan membantu mereka menetapkan batasan-batasan masalah moral yang akan dihadapi dalam melakukan penyesuaian sosialnya kelak. 


\section{Penalaran Moral}

Penalaran moral (moral reasoning atau moral judgement) adalah suatu pemikiran tentang masalah moral sebagai prinsip yang dipakai dalam menilai dan melakukan suatu tindakan dalam situasi moral. Penalaran moral bukanlah pada apa yang baik atau yang buruk, tetapi pada bagaimana seseorang berpikir sampai pada keputusan bahwa sesuatu adalah baik atau buruk (Kohlberg, L. 1981:19).

Seorang anak memerlukan suatu pengetahuan dengan memasukkan informasi, gagasan-gagasan dan nilai-nilai dari luar dirinya yang kemudian diolah dalam pemikiran anak menjadi suatu konsep, paradigma atau cara pandang terhadap nilai moral untuk membentuk suatu perilaku moral. Kematangan moral berdasarkan pada penalaran yang diberikan terhadap sesuatu hal yang benar atau salah.

Perilaku moral pada umumnya merupakan unsur fundamental dalam bertingkah laku sosial. Anak-anak tidak dapat diharapkan berperilaku yang sesuai secara sosial jika mereka tidak memahami hubungan sosial antara individu dan kaitannya dengan perilaku orang lain. Proses transformasi nilai-nilai moral terjadi melalui sosialisasi. Sosialisasi adalah proses belajar nilai-nilai dan aturan-aturan perilaku pada lingkungan budaya seseorang dilahirkan dan bertempat tinggal. Tugas dasar dari sosialisasi pada setiap budaya adalah mengkomunikasikan standar etika dan pembentukan serta penguatan kebiasaan perilaku yang baik pada pertumbuhan anak. Seorang anak yang semakin mahir memproses informasi sosial akan semakin mampu merespons situasi sosial dengan tepat.

Model pertukaran informasi sosial pada anak menjelaskan proses informasi sosial yakni bagaimana anak menerima informasi sosial untuk memilih respons sosial yang tepat. Kenneth Dodge dan rekan-rekannya merumuskan sebuah teori yang menggambarkan proses mental yang terlibat dalam menilai informasi sosial. Berikut model pertukaran informasi pada anak:. Anak berinteligensi tinggi membutuhkan pengalaman belajar yang sama dengan anak-anak pada umumnya dalam mendapatkan kesempatan untuk memperoleh pengalaman belajar yang dapat mendorong mereka untuk lebih peduli terhadap orang lain dan dengan kelebihan-kelebihannya dapa membantu anak lain berkembang secara optimal. Namun tingginya aspek intelektual pada anak berinteligensi tinggi berpengaruh sangat besar terhadap perkembangan personalitasnya yang dapat berdampak terhadap perkembangan sosialnya. 


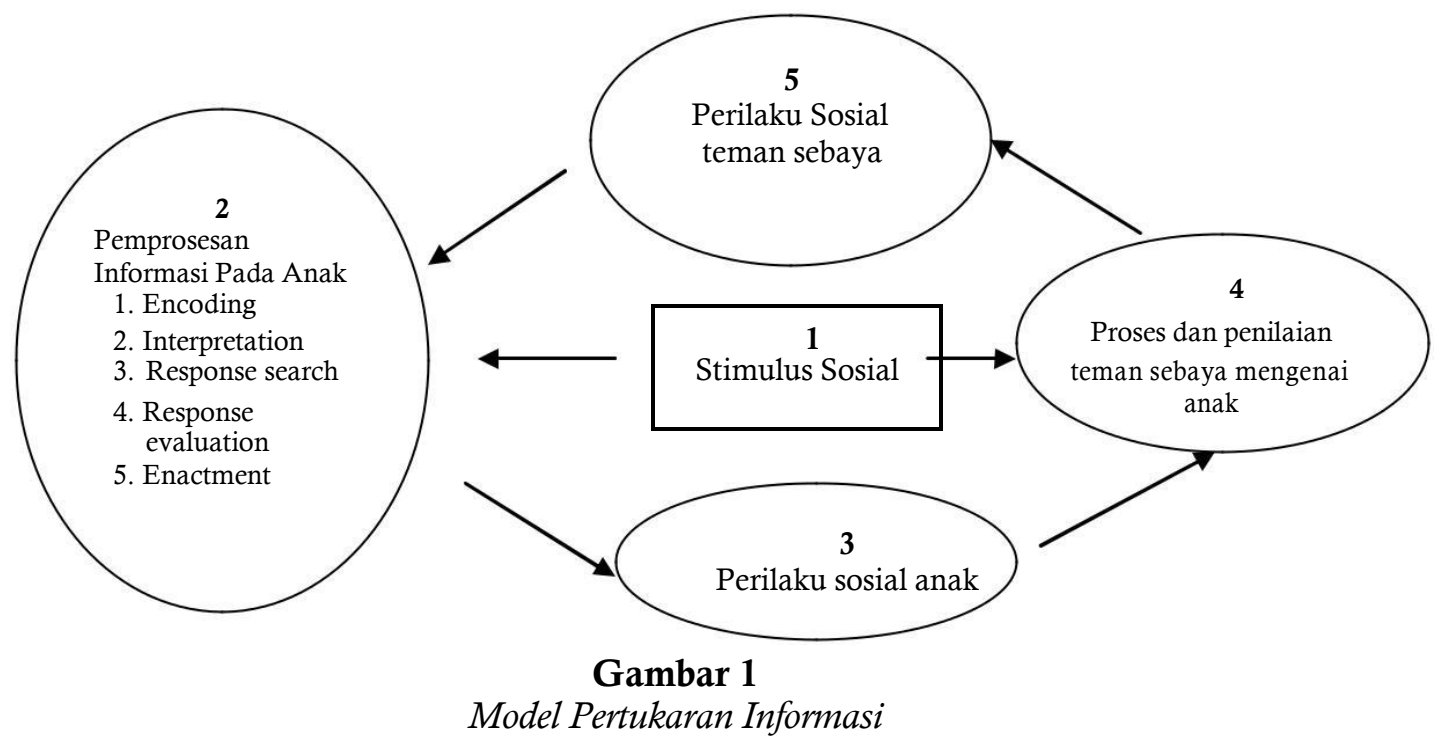

Model pertukaran informasi di atas menjelaskan bahwa stimulus sosial yang muncul diproses oleh pemikiran anak mela lui lima tahap :

1. Encoding. Anak pertama kali harus memberi kode/lambang terhadap stimulus sosial. Hal ini menjelaskan bahwa anak harus memperhatikan dengan tepat dan cukup memahami signal sosial. Anak harus mengetahui isyarat apa yang penting untuk mengkodekan sesuatu.

2. Interpretation. Sekali memberikan kode, informasi sosial harus diterjemahkan untuk menentukan makna/arti, oleh karena itu anak harus membandingkan informasi ini dengan apa yang mereka sudah ketahui.

3. Response search. Sekali suatu interpretasi telah dibuat, anak harus memutuskan apa tindakan selanjutnya. Anak harus mengeneralisasi berbagai alternatif/pilihan respons.

4. Response evaluation. Ketika respon telah digeneralisasi, maka responrespon tersebut harus dievaluasi. Pada apa yang dapat diatasi anak akan akibat perilakunya, anak akan memilih respon alternatif yang paling baik dalam situasi sekarang.

5. Enactment. Akhirnya, anak harus melakukan/melaksanakan respon yang dipilihnya. Stimulus sosial yang telah diproses melalui lima tahap tersebut menjadi informasi yang diperlukan guna berfungsinya pemikiran moral seorang anak sehingga diharapkan berperilaku yang sesuai situasi social (Bjourklund. 2005: 27).

Anak yang tidak mahir memproses informasi sosial akan menemukan kesulitan untuk dapat berperilaku yang sesuai secara sosial, itu sebabnya anak akan menunjukkan tingkat perilaku negatif. Perilaku anak kemudian dinilai oleh teman sebayanya apakah sesuai dan dapat diterima. Jika anak 
mahir memproses informasi sosial, anak akan berperilaku yang sesuai situasi sosial dan perilaku tersebut diterima menjadi perilaku sosial teman sebayanya.

Anak berinteligensi tinggi memiliki karakteristik khas. Morelock dan Feldman juga mengemukakan bahwa anak berinteligensi tinggi sejak dini sudah menunjukkan kemampuan atau kecakapan yang tinggi daripada anak-anak seusianya dalam kemampuan akademik. Kompleksitas kognitifnya membangkitkan kedalaman emosi, sehingga anak berinteligensi tinggi tidak hanya berfikir secara berbeda dari anak seusianya, melainkan juga merasa dengan cara yang berbeda (Deleeuw, N. S. 2002: 175).

Peristiwa kehidupan sehari-hari mengandung dilema moral yang menuntut setiap individu merespons secara tepat dan benar. Kemampuan ini dipengaruhi salah satunya oleh penalaran moral untuk menilai apakah suatu tindakan benar atau salah, baik dan buruk. Anak-anak memperoleh kemampuan mengontrol diri dari dorongan-dorongan gerak hati melalui penguatan atas kepatuhan dan sanksi karena perbuatan yang salah. Anak mengkonstruksi konsep moral dari interaksi sosial (pengalaman dalam hal kerjasama dan konflik) berdasarkan perkembangan kognitif dan emosi mereka (Berns, R.B. $2004: 19$ ).

Gross dalam penelitiannya menyatakan bahwa tingginya kapasitas intelektual pada anak berinteligensi tinggi mengakibatkan anak mempersepsi rangsangan dari lingkungan sosial lebih tinggi dari tahap penalaran moral teman seusianya. Terdapat ambang batas tertentu dimana kepekaan perasaan yang intensif mempersulit anak berinteligensi tinggi dalam melakukan penyesuaian sosial yang adaptif. Anak berinteligensi tinggi menggunakan strategi proses informasi yang biasanya dipakai oleh anak yang beberapa tahun diatas usianya sehingga anak berinteligensi tinggi lebih menyukai berinteraksi dengan anak anak yang beberapa tahun diatas usianya. Berdasarkan penelitian, semakin lama anak-anak bersama dengan anak yang beda usia pada program asuh anak, mereka akan lebih sering memperlihatkan dan memahami beberapa aspek perkembangan moral yang membantu perilaku dan kemampuan cara pandang (konsep) mereka mengenai moral (Derscheid, L.E. 1997:147).

Jenis kelamin merupakan suatu aspek identitas individu yang sangat penting yang lebih lanjut akan digunakan untuk meninjau peranannya dalam perkembangan moral anak. Perbedaan jenis kelamin antara laki-laki dan perempuan merupakan suatu bentuk aturan sosial yang diperoleh dari pengatribusian dari aspek sosialisasi. Dengan demikian ketika terjadi suatu ketidakseimbangan antara laki-laki dan anak perempuan dikarenakan adanya ketidakseimbangan peran yang diperoleh dari status antara laki-laki dan perempuan ditengah-tengah masyarakat akan mempengaruhi kognitif yang berbeda antara laki-laki dan perempuan yang pada akhirnya akan mempengaruhi penalaran moral (Archer, J. 1996 : 914). 
Pada penelitian ini peran jenis kelamin digunakan untuk melihat pengaruh pola asuh terhadap perbedaan penalaran moral anak laki-laki dan perempuan berinteligensi tinggi.Pola asuh diartikan sikap dan cara ayah dan ibu dalam menunjukkan otoritasnya dengan cara memberikan perhatian dan tanggapan-tanggapan terhadap keinginan-keinginan anak, mendidik, mengontrol, mendisiplinkan dan melindungi anak dari berbagai tindakan sesuai nilai-nilai moral. Ada beberapa bentuk pola asuh yaitu sebagai berikut:

1. Pola asuh otoriter (authoritarian parenting), yaitu bentuk pola asuh yang membatasi dan menuntut anak untuk mengikuti perintah-perintah orang tua tanpa menghormati pekerjaan dan usaha anak.

2. Pola asuh otoritatif (authoritative parenting), yaitu bentuk pola asuh yang mendorong anak-anak agar mandiri tetapi masih menetapkan batas-batas dan pengendalian atas tindakan-tindakan mereka.

3. Pola asuh permisif, yaitu pola asuh yang tidak memiliki tuntutan apapun (undemanding) pada anak dan responsive yang ditandai dengan rendahnya tuntutan, kontrol dan komunikasi (Bee, H. 1997 dalam Syah, 2000: 43).

Nilai-nilai moral dari orang tua diinternalisasi oleh anak melalui pola asuh orang tuanya akan menentukan bagaimana anak mampu memahami dan berperilaku sesuai nilai-nilai moral yang ada di lingkungannya. Memberikan kesempatan pada anak untuk bertanya mengenai penalaran dan perilaku moralnya sendiri akan membantu perkembangan moral anak. Albert Bandura dalam pendekatan teori belajar sosialnya menekankan perlunya conditioning (pembiasaan merespons) dan imitation (peniruan) dalam proses perkembangan moral. Dasar pemikiran conditioning adalah sekali seorang anak mempelajari perbedaan perilaku yang menghasilkan ganjaran dengan perilaku yang mengakibatkan hukuman, ia senantiasa berpikir dan memutuskan perilaku moral mana yang perlu ia buat. Komentar-komentar yang diungkapkan ketika mengganjar/menghukum anak merupakan faktor penting untuk proses internalisasi atau penghayatan anak tersebut terhadap moral standards atau patokan-patokan moral (Bee, $\mathrm{H}$. 1997).

Keputusan moral, jelas melibatkan proses berpikir bahwa semakin negatif pikiran seseorang, maka semakin gelap dan tebal rajutan distorsi kognitifnya, begitu pula sebaliknya semakin positif pikiran seseorang semakin jelas dan mudah rajutan distorsi kognitifnya sehingga sikap dan pola pikir sangat tergantung pada cara pandang seseorang melihat peran dirinya di dalam keluarga (Oemardi, K.A. 2004). Perbedaan perkembangan moral memiliki hubungan dengan penerapan disiplin orang tua dalam pola asuhnya berdasarkan gender anak. Ada beberapa alasan. Pertama, anak lakilaki dan perempuan berbeda pada seluruh tingkatan internalisasi moral. Kedua, orang tua menggunakan tipe dan atau tingkat disiplin yang berbeda untuk anak laki-laki dan perempuan sehingga akan mempengaruhi 
internalisasi anak-anak terhadap pesan-pesan dan ungkapan orang tua tentang perilaku moral. Ketiga, hubungan antara beberapa tipe disiplin orang tua dan dampaknya pada anak diperantarai oleh gender anak. Misalnya, menurut meta-analisis, hubungan antara perilaku pengasuhan dan eksternalisasi moral lebih kuat pada anak laki-laki daripada anak perempuan. (David C. R., Nestor L. Lopez. 2004:372)

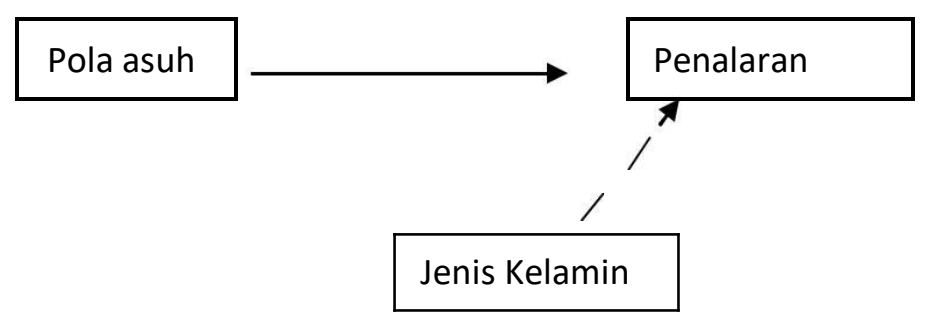

\section{Gambar 2}

Hubungan Pola Asuh Orangtua Dengan Penalaran Moral Anak

Dalam penelitian penulis, diasumsikan bahwa penalaran moral anak ditentukan pada bagaimana pengalaman pembiasaan membuat keputusan moral yang diterima anak melalui pola asuh orang tuanya.

\section{METODE}

\section{Lokasi Penelitian}

Penelitian ini dilakukan di SD Muhammadiyah II J1. Bimokurdo no.33 Sapen Yogyakarta dengan alasan merupakan satu-satunya SD swasta favorit yang mendapat ijin dari Depdiknas sebagai SD penyelenggara program akselerasi pertama di Yogyakarta dan jumlah siswa berinteligensi tinggi dapat mencukupi untuk dijadikan subjek penelitian.

\section{Subjek Penelitian}

Subjek penelitian ini adalah siswa-siswa program akselerasi kelas V patas 1 dan patas 2 di Sekolah Dasar yang berjumlah 81 orang. Pengambilan subjek dilakukan dengan teknik purposive sampling, dengan karakteristik: berusia 1011 tahun, terdiri dari siswa laki-laki dan perempuan, memiliki intelegensi dalam kategori di atas rata-rata dan superior dan masih memiliki kedua orang tua (bapak dan ibu).

Pengambilan siswa kelas V Patas sebagai subjek penelitian berdasarkan faktor usia, yaitu antara 10 sampai 11 tahun, siswa SD kelas V termasuk kategori kanak-kanak akhir dan menurut Kohlberg pada usia ini anak sudah mencapai perkembangan moral pada tahap memperhatikan 
citra anak baik dan tahap memperhatikan hukum dan peraturan (Berndt, Thomas J, 1992: 42).

Pengambilan siswa kelas V Patas sebagai subjek penelitian yang memiliki inteligensi tinggi didasarkan hasil tes IQ yang dilakukan oleh tim psikolog Universitas Gajah Mada dengan wawancara dan tes CFIT dengan alasan dapat mengungkap karakteristik emosional dan motivasional tertentu pada anak. Hasil tes berupa IQ (Intellegence Quotient) dengan melihat perbandingan antara MA (Mental Age) dan CA (Chronological Age) yang dikalikan 100. Hasil penyaringan dari 187 siswa ditetapkan pada tanggal 6 November 2004 yaitu 81 orang direkomendasikan mengikuti program akselerasi atau masuk kelas PATAS (Program Percepatan Tuntas).

\section{Metode dan Alat Pengumpul Data}

Metode pengumpulan data dalam penelitian ini menggunakan metode skala, yaitu:

1. Skala Penalaran Moral Anak. Skala ini berisi 30 aitem untuk mengukur sepuluh aspek moral dasar yaitu aspek kejujuran, adil, keteguhan hati, pemaaf, kesetiaan, menghargai, tanggung jawab, kerja sama, empati, dan suka penolong/berbagi.

2. Skala Pola Asuh Orang tua. Skala ini berisi 30 aitem untuk mengumpulkan data tentang pola asuh yang diterapkan orangtua menurut persepsi anak.

Data yang terkumpul dan memenuhi syarat, diuji normalitas dan homogenitasnya kemudian dianalisa untuk menguji apakah hipotesis yang diajukan diterima atau tidak. Analisis data dalam penelitian ini dilakukan dengan program Statistical Package for Social Science (SPSS) for Windows Release 11.0 dan analisis perbandingan ganda (Multiple Comparison Analysis) dan uji two ways ANOVA.

\section{HASIL}

Sesuai hasil perhitungan dengan teknik analisis varians dua arah diketahui bahwa hipotesis penelitian yang mengatakan bahwa ada perbedaan penalaran moral siswa berinteligensi tinggi ditinjau dari pola asuh orang tua, diterima. Hasil penelitian yang menunjukkan bahwa pola asuh dan jenis kelamin saling berinteraksi dalam mempengaruhi penalaran moral siswa berinteligensi tinggi, yaitu sebagai berikut:

1. Khusus pada sampel laki-laki

a. Tidak ada perbedaan penalaran moral siswa yang memperoleh pola asuh otoriter dibandingkan dengan siswa yang memperoleh pola asuh otoritatif.

b. Tidak ada perbedaan penalaran moral antara siswa yang memperoleh pola asuh otoriter dibandingkan dengan siswa yang memperoleh pola asuh permisif. 
c. Ada perbedaan penalaran moral yang signifikan antara siswa yang memperoleh pola asuh otoritatif dibandingkan dengan siswa yang memperoleh pola asuh permisif yakni penalaran moral siswa yang memperoleh pola asuh otoritatif lebih tinggi daripada penalaran moral siswa yang memperoleh pola asuh permisif

2. Khusus pada sampel perempuan

a. Tidak ada perbedaan penalaran moral yang signifikan antara siswi yang memperoleh pola asuh otoriter dibandingkan dengan siswi yang memperoleh pola asuh otoritatif.

b. Tidak ada perbedaan penalaran moral yang signifikan antara siswi yang memperoleh pola asuh otoritatif dibandingkan dengan siswi yang memperoleh pola asuh permisif

Tidak ada perbedaan penalaran moral yang signifikan antara siswi berinteligensi tinggi yang memperoleh pola asuh otoriter dibandingkan dengan siswi yang memperoleh pola asuh permisif.

Dengan demikian asumsi adanya perbedaan penalaran moral siswa berinteligensi tinggi ditinjau dari pola asuh orang tua telah dibuktikan. Aspek psikologis turut mempengaruhi penalaran moral seseorang. Perbedaan ini terjadi ketika individu berhadapan dengan masalah yang kompleks akan menanggapinya dengan mengurangi masalah pada tingkatan mana masalah itu dapat difahaminya. Setiap anak memiliki kemampuan yang berbeda di dalam menyikapi suatu masalah. Anak berinteligensi tinggi khususnya, dimana kapasitas intelektualnya yang sangat tinggi menyebabkan munculnya sikap skeptis dan kritis, cepat bosan, memaksakan atau mempertahankan pendapatnya, sensitif, kurang tenggang rasa dan tidak mudah tunduk terhadap tekanan, semuanya dapat menjadi penyebab ketidakmampuan anak memahami dirinya yang dapat berakhir dengan munculnya perasaan ditolak atau kurang dimengerti oleh lingkungannya.

Kepekaan perasaan ini mengarahkan anak berinteligensi tinggi untuk mempersepsi sinyal-sinyal sosial secara tidak tepat sehingga berpengaruh guna berfungsinya pemikiran moral untuk berperilaku sesuai situasi sosial. Ketidakmampuan anak di dalam memahami dirinya untuk berperilaku sesuai nilai moral terjadi karena anak belum dapat mengkonstruksikan dan memfungsikan kognisi sosial dengan efektif dan rasional. Untuk itu perlu adanya bimbingan dan dukungan dari orangtua.

Kemampuan orang tua anak berinteligensi tinggi dalam menstimulasi akan menentukan perkembangan kemampuan anak berinteligensi tinggi dalam perkembangan penalaran moral. Sesuai pernyataan Walker dan Hennic (1991) bahwa tidak adanya dukungan dari orangtua dapat mempengaruhi perkembangan penalaran moral anak karena dukungan orangtua merupakan suatu stimulus positif yang akan mempengaruhi perkembangan penalaran moral. Rasa ingin tahu yang sangat besar dan 
sikap kritis menyebabkan anak berinteligensi tinggi suka menentang tradisi dan peraturan yang mengekangnya (Walker \& Hennic 1999:361).

Orangtua otoritatif yakni orang tua yang berusaha mengenal pandangan anak, dan mendorong terjadinya perbandingan pandangan lewat dialog, akan membantu anak berinteligensi dalam menetapkan keputusan moral. Melalui pola asuh otoritatif, anak berinteligensi tinggi belajar memahami sendiri batasan-batasan moral yang harus dipegangnya tanpa merasa dikekang. Pengasuhan otoritatif membantunya menumbuhkan keyakinan dan kepercayaan diri serta mendorong tindakan-tindakan mandiri membuat keputusan sendiri sehingga berakibat munculnya tingkah laku mandiri yang bertanggung jawab. Beda halnya jika anak berinteligensi tinggi memperoleh pola asuh permisif, dimana orang tua cenderung selalu memberikan kebebasan pada anak tanpa memberikan kontrol sama sekali. Anak diberikan kesempatan sebebas-bebasnya untuk berbuat dan memenuhi keinginannya. Hal ini akan membuat anak merasa tidak digubris atau tidak diperdulikan seluruh perbuatannya maka ia akan mencari perhatian dengan cara menampilkan perbuatan yang negatif yang dapat mencemarkan nama baik keluarganya. Jika tindakan negatif mendapat penguatan maka anak akan lebih sering melakukan tindakan yang negatif. Hal ini sejalan dengan hasil penelitian ini dimana anak berinteligensi tinggi baik laki-laki maupun perempuan yang memperoleh pola asuh otoritatif dan pola asuh permisif menunjukkan adanya perbedaan penalaran moral, dimana anak laki-laki dan anak perempuan yang memperoleh pola asuh otoritatif memiliki penalaran moral yang lebih tinggi daripada anak laki-laki dan anak perempuan yang memperoleh pola asuh permisif.

Tidak adanya perbedaan penalaran moral pada anak berinteligensi tinggi laki-laki dan perempuan baik yang diasuh dengan pola asuh otoriter maupun pola asuh permisif dimungkinkan karena pola asuh otoriter memang membatasi hak anak tetapi tetap menuntut tanggung jawab seperti anak dewasa, memaksa anak-anak untuk patuh pada nilai-nilai orang tua, serta mencoba membentuk tingkah laku anak sesuai dengan tingkah laku orang tuanya akan mengakibatkan anak berinteligensi tinggi merasa terkekang dan dibatasi keinginan dan hasratnya yang besar untuk untuk mencari nilai-nilai baru yang kemungkinan bertolak belakang dengan norma-norma masyarakat yang sudah mapan.

Benturan nilai-nilai yang dimiliki anak berinteligensi dengan nilainilai yang diajarkan dan dituntut orang tuanya memungkinkan terjadinya konflik sosio kognitif pada anak sehingga mempengaruhi anak berinteligensi tinggi dalam membuat keputusan moral. Demikian pula dengan siswa yang memperoleh pola asuh permisif, sikap orang tua yang terlalu membebaskan pemikiran anak berinteligensi tinggi dalam membuat keputusan sendiri akan memungkinkan anak belajar menyelesaikan sendiri konflik sosio kognitif yang dialami akibat benturan nilai-nilai yang dialami 
dengan nilai-nilai diterimanya sehingga juga dapat mempengaruhi anak dalam membuat keputusan moral.

Tidak adanya perbedaan penalaran moral pada anak laki-laki dan anak perempuan berinteligensi tinggi antara yang memperoleh pola asuh otoriter dibandingkan yang memperoleh pola asuh otoritatif dimungkinkan karena pola asuh otoriter merupakan cara melatih dan mengatur anak lakilaki berinteligensi tinggi untuk terlibat dan mendekat secara fisik walaupun menekankan dominasi orang dewasa. Menurut Greenfield \& Suzuki (dalam Berns 2004), kondisi-kondisi tertentu seperti kondisi lingkungan sekitar anak yang dianggap berbahaya mendorong orang tua untuk memberikan disiplin yang keras bukan untuk mendominasi tetapi untuk menjaga dan melindungi integritasnya, melindungi, serta menjaga hubungan yang harmonis dengan orang lain serta agar anak laki-laki tidak terjebak dalam aktivitas-aktivitas anti sosial atau merusak moral. Sedangkan pola asuh otoritatif akan memotivasi anak laki-laki berinteligensi tinggi untuk belajar dan berperilaku menurut harapan-harapan orang tua, yang pada akhirnya dapat mempengaruhi anak di dalam mengambil suatu keputusan atau di dalam melakukan penalaran moral.

Tidak adanya perbedaan penalaran pada anak perempuan yang memperoleh pola asuh otoriter dibandingkan dengan anak perempuan yang memperoleh pola asuh otoritatif dimungkinkan karena bahwa emosi perempuan lebih besar daripada anak laki-laki dan anak perempuan kurang tegas atau mudah bimbang dan memiliki kecemasan (Archer, 1996). Anak perempuan memiliki respon emosi yang berbeda dengan anak laki-laki ketika mengalami ketegangan. Menurut Campbell (1993 dalam Chesney, 2004), rasa marah pada anak perempuan disertai emosi-emosi seperti rasa takut, cemas, merasa bersalah dan rasa malu; sedangkan rasa marah pada anak laki-laki ditandai dengan amukan atau menentang nilai-nilai moral. Anak perempuan ketika marah cenderung menyalahkan diri sendiri karena mereka khawatir kemarahannya akan membahayakan orang lain dan merusak hubungan dengan orang lain. Orang tua otoritatif yang menunjukkan sikap simpatik, hangat dan mendukung akan membantu anak perempuan berinteligensi tinggi agar dapat mengatur emosi secara efektif sehingga termotivasi untuk belajar dan berperilaku menurut harapanharapan orang tua sehingga mampu membuat keputusan moral dengan baik. Hal ini sesuai pernyataan Mathias (1987), ketika melakukan penalaran moral, anak berpikir mengenai soal-soal moral berdasarkan motivasi yang ada di dalam diri individu yang kemudian dituangkan ke dalam bentuk pilihan di dalam melakukan penalaran moral. Sebaliknya orang tua otoriter yang cenderung keras dan sering menerapkan disiplin yang keras, bagi anak perempuan yang sensitifitas emosinya tinggi akan membuat anak perempuan menyimpan perasaannya dan keinginannya padahal ketika orangtua memberikan tuntutan dan harapan seharusnya memberikan penawaran alasan atau pembenaran sehingga menyebabkan anak 
perempuan beresiko mengalami lebih banyak konflik sosio kognitif yang pada gilirannya berpengaruh terhadap perkembangan penalaran moralnya.

Pola asuh orang tua berpengaruh terhadap penalaran moral siswa laki-laki dan perempuan berinteligensi tinggi. Hal ini sejalan dengan salah satu perspektif teoritis utama tentang perbedaan jenis kelamin dalam membentuk perilaku, yaitu perspektif teori proses belajar yang menekankan adanya proses dalam pembentukan perilaku seperti penguatan dan peniruan seseorang memperoleh ciri-ciri menetap yang berkaitan dengan jenis kelamin. Orang tua melalui tindakan dan contoh mempengaruhi anak lakilaki dan perempuan untuk menyesuaikan diri dengan norma-norma moral yang ada dalam lingkungan budayanya (ears, David O., Freedman, Jonathan L. 1994: 48).

Sinyal-sinyal perlakuan yang bertujuan untuk membedakan antara laki-laki dan perempuan dalam masyarakat sesungguhnya telah ada, yang kemudian meresap sejak mereka kanak-kanak, bahwa ia laki-laki maka ia harus begini dan karena ia perempuan ia harus begitu. Perbedaan perlakuan berdasarkan gender ini menjadi norma sejak anak-anak sangat muda, yang selanjutnya menjadi lebih kuat dan nyata di dalam kehidupan sosial. Terjadinya perubahan-perubahan psikologis pada siswa perempuan berinteligensi tinggi ini sebagai akibat dari adanya konflik antara kebutuhan psikologis dengan pengharapan masyarakat terhadap peran gender, anak perempuan sejak kecil belajar dari keluarganya, sekolah, dan media massa mengenai perilaku yang dapat diterima kelompok (keluarga, sekolah, dan masyarakat), dan anak perempuan berinteligensi tinggi juga mempelajari hal-hal yang ditolak kelompoknya, dan ia berusaha untuk menghindarinya (Widyorini, Endang, 2007).

Orang tua memiliki kecenderungan bertindak berbeda terhadap anak laki-laki dan perempuan dalam berperilaku yang sesuai dengan nilai moral yang berlaku dalam masyarakatnya, dimana ketika menerapkan pola asuh orang tua memiliki harapan-harapan perilaku tertentu menurut jenis kelamin anaknya sehingga memungkinkan anak laki-laki dan perempuan mendapatkan kesempatan alih peran yang berbeda di dalam pembelajaran moral. Hal ini sejalan dengan teori belajar sosial bahwa anak-anak belajar bersikap dan berperilaku yang sesuai dan tidak sesuai dengan perilaku gender melalui observasi dan peniruan dari perbedaan perlakuan orang tua terhadap anak laki-laki dan perempuan.

Anak perempuan akan mengobservasi perilaku yang diharapkan orang tua menurut peran jenis kelaminnya dan demikian pula anak lakilaki. Namun demikian, suatu lingkungan tertentu akan memiliki pengaruh yang berbeda tergantung pada kecenderungan-kecenderungan anak laki-laki dan perempuan dalam membangun versi mereka sendiri tentang pola -pola perilaku secara aktif. Dalam kehidupan sehari-hari, anak laki-laki dan perempuan menggunakan bakat dan dorongan dasar mereka dengan cara yang ada kaitannya dengan jenis kelamin. 
Penanaman nilai kepada anak dilakukan melalui penanaman kebiasaan, yang akan berakumulasi menjadi kepribadian anak dan muncul dalam bentuk penalaran dan perilaku moralnya. Model dari orangtua di dalam mensosialisasikan dan menerapkan pembelajaran moral pada anak laki-laki dan perempuan dalam kondisi tertentu mendukung terjadinya perbedaan perkembangan penalaran moral antara anak laki-laki dan perempuan. Beberapa alasan mengapa penerapan disiplin orang tua dalam pola asuhnya memiliki hubungan dengan perkembangan moral berbeda berdasarkan gender anak. Pertama, anak laki-laki dan perempuan berbeda pada seluruh tingkatan internalisasi moral. Contoh, sejak masa kanak-kanak awal, anak perempuan menunjukkan tingkatan yang lebih tinggi dari rasa bersalah, empati dan kematangan kognitif sosial, semuanya memiliki hubungan konseptual dengan perkembangan moral. Kedua, orang tua menggunakan tipe dan atau tingkat disiplin yang berbeda untuk anak lakilaki dan perempuan sehingga akan mempengaruhi internalisasi anak-anak terhadap pesan-pesan dan ungkapan orang tua tentang perilaku moral. Ketiga, hubungan antara beberapa tipe disiplin orang tua dan dampaknya pada anak diperantarai oleh gender anak (David C. R., Nestor L. Lopez. $2004: 375)$.

Perbedaan jenis kelamin antara anak laki-laki dan anak perempuan merupakan suatu bentuk aturan sosial yang diperoleh dari pengatribusian dari aspek sosialisasi. Bagi anak berinteligensi tinggi yang tidak didukung oleh lingkungan sosial sebenarnya bukan sesuatu yang mudah, apalagi subjek dalam penelitian ini lahir dan dibesarkan dalam masyarakat Jawa yang lebih mengutamakan kepatuhan dan kesopanan pada seorang anak, atau menolak spontanitas dalam mengungkapkan diri karena dianggap tidak etis. Sementara anak berinteligensi tinggi dengan berbagai bakat yang dimiliki kurang bisa melakukan hal-hal yang konvensional, mereka suka pembaharuan, mempunyai ide banyak, dan punya minat yang bermacammacam, bahkan kadang-kadang mereka nampak tidak konformis. Sementara dalam masyarakat Jawa mengutamakan tingkah laku dan adat sopan santun terhadap orang tua. Orang hidup harus sesuai dengan peraturan moral, harus mampu melawan dan menunda terpenuhinya kebutuhan diri (Archer, J. 1996:914).

Hal ini tentunya dapat menimbulkan konflik tersendiri bagi anak berinteligensi tinggi. Dalam budaya Jawa antara laki-laki dan perempuan mendapat perlakuan dan tuntutan yang berbeda secara cukup menyolok. Keluarga Jawa mempunyai pandangan dan harapan yang berbeda pada anak laki -laki dan perempuan. Pandangan ini mempengaruhi pengasuhan orangtua yang telah ditanamkan sejak mereka bayi.

Pembagian peran berhubungan dengan hal-hal apa yang boleh dilakukan dan siapa yang boleh melakukan mempengaruhi pemahaman mengenai partisipasi masing-masing jenis kelamin dalam kehidupan bermasyarakat. Dengan demikian ketika terjadi suatu ketidakseimbangan 
peran yang diperoleh dari status antara anak laki-laki dan anak perempuan, pada akhirnya akan mempengaruhi kognitif yang berbeda antara anak lakilaki dan anak perempuan yang pada akhirnya berpengaruh terhadap perkembangan penalaran moralnya.

\section{DISKUSI}

Pola asuh dan jenis kelamin telah terbukti saling berinteraksi dalam mempengaruhi penalaran moral anak berinteligensi tinggi. Dengan hasil penelitian yang di dapat tersebut, disarankan bagi pendidik hendaknya mengembangkan strategi mengajar yang tepat yang dapat mengembangkan aspek positif bagi anak berinteligensi tinggi dengan (a) menghindari stereotip peran jenis kelamin; (b) memberi dorongan bagi anak beringeligensi tinggi untuk independen dan berani mengambil resiko; (c) membimbing mereka dalam perilaku problem solving dan strategi

pengambilan keputusan. Bagi orang tua, hendaknya hendaknya menghindarkan pola pengasuhan atau tuntutan (harapan) yang berbeda bagi anak laki-laki dan perempuan dan membantu mereka menetapkan batasanbatasan dalam membuat keputusan moral secara tepat sehingga terhindar dari masalah penyesuaian sosial.

\section{DAFTAR PUSTAKA}

Archer, J. 1996. Sex Differences in Social Behavior : are the social role and evolutionary explanations compatible?. American Psychological Association, Vol. 51, (9), 909-917

Bee, H. 1997. The Developing Child. New York: Harper \& Row Publisher.

Berndt, Thomas J. 1992. Child Develop ment. Florida : Rinehart \& Winston Inc

Berns, R.B. 2004. Child, Family, School and Community : socialization and support. Belmont : Thomson Learning Inc.

Bjourklund. 2005. Children's Thinking : cognitive development and individual differences. New York : Jhon Willey and Son Inc

David C. R., Nestor L. Lopez. 2004. Parental Discipline and Externalizing Behavior Problems in Childhood : the Roles of Moral Regulation and Child Gender. Journal of Abnormal Child Psychology, Vol. 32, (4) : 369-383

Deleeuw, N. S. 2002. Gifted Preschoolers : Parent and Teacher View on Identification, Early Admission and Programming. Rooper Review , 21 (3) : 174-179

Derscheid, L.E. 1997. Mixed-age Grouped Preschoolers‘ Moral Behavior and Understanding. Journal of Research in Childhood Education, (11) : 147- 151 
Kohlberg, L. 1981. The Philosophy of Moral Development, Moral Stages, and Idea of Justice. San Francisco : Harper \& Row Publisher

Oemardi, K.A. 2004. Pendekatan Cognitive Behavior dalam Psikoterapi. Jakarta: Kreatif Media.

Sears, David O., Freedman, Jonathan L. 1994. Psikologi Sosial. Jilid 2. Alih bahasa : Michael Adriyanto, Jakarta : Erlangga

Walker, L. J. \& Hennic, K. H. 1999. Parenting Style and the Development of Moral Reasoning. Journal of moral education, 28 (3), 360-374 Widyorini, Endang. Perempuan Berbakat Dalam Budaya Jawa. Tesis. (tidak diterbitkan). Yogyakarta : Universitas Gajah Mada

Widyastono, 2005. Sistem Percepatan Kelas (Akselerasi) bagi Siswa yang Memiliki Kemampuan dan Kecerdasan Luar Biasa. www.pdk.go.id/balitbang/Publikasi/Jurnal/No_026/.htm 
